\title{
Use of Environmental Psychology and Feng Shui for a More Supportive Living Environment
}

\author{
Špela Kryžanowski \\ Studio ARHITELJE d.o.o./Faculty for Design, Trzin, Slovenia
}

\author{
Citation: Kryžanowski š. Use of Environmental Psychology an \\ Feng Shui for a More Supportive Living Environment. SEE \\ Archit Des. 2015 Dec 09; 2015:10009. http://dx.doi.org \\ Key words: environmental psychology; feng shui; Vital house. \\ 'Correspondence: Špela Kryžanowski. Studio ARHITELJE \\ d.o.o./Faculty for Design, Trzin, Slovenia. E-mail: \\ spela.kry@gmail.com \\ Received: 02-Nov-2015; Revised: 29-Nov-2015; Accepted: \\ 01-Dec-2015; Published: 09-Dec-2015 \\ Copyright: (c) 2015 Špela Kryžanowski. This is an open- \\ under the terms of the Creative \\ Commons Attribution License, which permits unrestricted use, \\ distribution, and reproduction in any medium, provided the \\ original author and source are credited. \\ Competing Interests: The author have declared that no \\ competing interests exist.
}

\begin{abstract}
„We shape our buildings and afterwards, our buildings shape us," is a quote by W. Churchill that illustrates the importance of the person - environment - well being relationship. Although there is no environmental determinism, our surrounding is an important factor in the way we feel and perform in build spaces. Environmental psychology developed numerous tools for analysing and evaluating these influences. Not all of these findings come to the attention of architects or designers or people in charge of public buildings (schools, health institutions, etc). The paper exposes some of the environmental psychology recommendations (importance of light, presence of nature) that can influence our behaviour and that we are usually not aware of. Apart from contemporary research there are some traditional arts that bring the spiritual dimension to the design of the built environment. The paper presents Chinese feng shui, as an example of design approach, which uses the manipulation of life force qi for a more supportive living environment. Finally the project of the Vital house is shown as an example of successful combination of contemporary and traditional approaches.
\end{abstract}

\section{Introduction}

„We shape our buildings and afterwards, our buildings shape us" [1], is a quote by Winston Churchill that illustrates the importance of the person - environment - well being relationship. Although there is no environmental determinism [2], our surrounding is an important factor in the way we feel and perform in build spaces [3]. The paper aims to explore whether, we can combine recommendations of different, sometimes even contradictory, design approaches in search of a more supportive living environment. Some recommendations of environmental psychology will be shown as an example of how contemporary science approaches the questions of environmental influences. As a contrast, traditional Chinese art of feng shui will be used as an example of spiritual approach to designing harmonious living environment. The aim of this contrasting is to show, how the same problem is addressed through two different concepts: a materialistic one, supported through contemporary experi- mental science and field analyses, and a spiritual one, based primarily on traditional Chinese philosophy. The final aim of the different design approaches would be a design concept that is able to overcome the apparent differences and gather all the relevant recommendations for supportive living environment into one final product.

The importance of supportive living environment is currently undervalued among architects and designers. The architect is primarily occupied with the creation of the space, during which he tries to take into account all the relevant facts, but he is rarely involved in the post evaluation studies of the created spaces. So it is not uncommon that architects don't really know, how the space they created functions in real life. Another problem is the superficiality and the constant quest of the new. Today the buildings and interiors are evaluated mainly from the photographs published in the design magazines without the real experience of the space they represent. And new trends are followed without really taking into account all the impacts they are bringing. So buildings get 
awarded by the architects that do not function that well with the users. For example, an architectural team was given an award for an innovative and bold reconstruction of a school in a degraded neighbourhood [4], but after a year the performance of the students continued to be below standards and eventually the high rates of vandalism were back in full swing. From the point of view of budget, schedule and visual appeal, the project was obviously successful. But taking into account the needs and aspirations of the people who live, work or use a particular space it was not that successful. There seems to be a huge gap between the theoretical findings of the environmental psychologists and the application of their findings into the design of built space [4]. Somehow the results of psychological analyses don't come to the attention and into the projects of architects and designers. One of the reasons is the lack of simple professional guides, books that would translate a rather dull scientific language published in psychological magazines, into an easy to understand guide books for designers and architects. The knowledge about traditional design approaches for supportive living environment is even poorer. If we look at the Chinese art of feng shui, although there are numerous lay books, there is very little scientific research that would be useful for an architect. And there are a lot of challenges to be overcome by a western designer (like language barrier, the infusion with the cultural believes and history of the country) if this traditional information is to be transferred to contemporary 21th century [5]. But if we want to follow Frankel's recommendation: "Great design requires greater knowledge about the human condition and how the spaces people inhabit power their ability to achieve success," [4] we must try to combine all the contemporary and traditional information for supportive environment available to us.

\section{Methods}

A representation of some environmental psychology and feng shui recommendations will be given to show two different approaches by which contemporary architectural practice could be enriched in the segment of focusing more on the influence of the environment parameters that influence our well-being.

\section{Environmental psychology and examples of recommendations for supportive living envi- ronment}

There are numerous works [3, 6] that give a comprehensive outline of environmental psychology. Since it is not possible to present all of the factors that affect a supportive living environment, we will focus on the two that are especially relevant for health and education institutions: the importance of the nature and the influences of light. Among general topics of environmental psychologists the relationship between nature and human is especially interesting. Nature seems to have a restorative effect on humans which can be best explained through the theory of stress reduction [7] and Attention restoration theory [8] and this knowledge can be particularly useful in medical settings. Roger Ulrich, 1984 [9] compared the postsurgical recovery of hospitalised patients whose rooms overlooked either a small group of trees or a brown brick building wall. Those patients with more natural view had fewer postsurgical complications, had faster recovery times and required fewer painkillers. Although the conclusions of the study can't be extended to all built views, the results imply that the hospital design should take into account the quality of patient window views. A substantial body of research has now demonstrated that stress and psychosocial factors can significantly affect patient health outcomes, along with the traditional factors of infection risk exposure and functional efficiency [10]. The last two factors were the ones that shaped the design of the medical institutions from the beginning of the 1900s onwards and turned our medical institutions into efficient health machines, generally unsuitable to fullfiel the emotional needs of the patients, their families and also healthcare staff. So it is encouraging to know that restorative effects of nature scenes (e.g. calm, pleasantness) can be manifested already within short period of three to five minutes [11]. A study of anxious patients in dental clinic showed, that the patients were less stressed when a large nature painting was hung on the wall of the waiting room in contrast to the days when the wall was blank [12]. There are other health related benefits that patients realise by simply passively looking at hospital gardens and plants, but restoration from stress and improved mood are by far the most important categories [13]. The fact that stress is a pervasive, well documented and very important health-related problem in hospitals only adds to the significance of these findings.

Not only plants, the aquariums also have a restorative and calming effect on the observers. In a fish tank we can see enough to understand what is happening, but we can't predict exactly what will happen next, and this captures our attention and diverts us from our current situation. Aquariums are usually more difficult to install and maintain in space than plants, but they are especially suitable for all the spaces where people might need some sort of help to relax: waiting rooms, lobbies where candidates wait for their interviews, break rooms for the stuff, cafeterias and other office spaces [4]. Art on the other hand has a miscellaneous effect on the observer. Abstract and ambiguous paintings and art can be a good choice for an office setting but a really bad one for a health institution. Researchers have learned that representational art showing open pastoral scenes with scattered trees and meadows that are rimmed with a 
forest, tended gardens and calm water are the three best choices to use in healthcare environments [14]. Chemotherapy patients who can see art with nature motives while being treated are 20 per cent less anxious than patient's who don't. Abstract art, on the other hand, should always come with a short description or a straightforward title. This would make the observer more in charge of the situation, giving him a feeling of understanding what a specific abstract piece of art is all about.

Sunlight is of utmost importance for any built environment as it helps our circadian rhythms being synchronised. According to environmental psychologists the general rule for the architects and designers should be: "The bigger and closer the windows, the better." [4]. Students in classrooms with more daylight learn better than students in darker classrooms [15]. And sunlight makes office workers happier with their jobs and improves their well-being in general. People who sit near a window are more tasks oriented, than people who sit far from the window, and they spend more time using their computer and doing the task they are paid for than their colleagues sitting away from the window. Sunlight is also important in health care settings. Post-operative patients who are placed in sunny rooms require less pain medications than patients assigned less sunny rooms, which reduces the cost of treating them. Patients in sunny rooms also feel less stressed and are released sooner. Morning sunlight is especially beneficial to patients with bipolar disorder, depression and senile dementia. Daylight is always combined with artificial light. The best way to do it is by combining user controlled task light (spot light on the working table for example) and a general indirect ambient lightning, where the source of the light can't be seen directly [4]. The artificial lightning in a space has as much influence on how workers or students perform as does the amount of daylight in the space. We prefer the indirect sources of light and perceive the indirectly lit spaces as more cheerful. Also the brightness of the lightning matters. If one wants to support ones creativity one should work in moderately lit spaces (around $150 \mathrm{lux}$ ). The same goes for the ability to reward the performance of others. For the support of the perseverance of the workers, higher levels of light (1500 lux) are more appropriate. Short term memory and problem solving are better under warm light $(3.000 \mathrm{~K}$ reddish yellow colour) and the same goes for long term memory of people in general (there are however differences when working with gender groups). As a result all brain storming rooms, offices requiring problem solving and in the same manner educational settings as well, should be equipped with warm lightning. Warm light also supports the resolving of interpersonal conflicts through collaboration so it is useful for arbiters and lawyers.

\section{Feng shui and supportive living environment}

The quest for supportive living environment is as long as the building art itself. Architecture and design of a particular period always portray the aspirations and values of the society that produced them. If for example, the building equalled a machine for living [16] to a functionalist that needed to house a growing population in the first decades of the last century, today it has to do more, and satisfy the emotional and sensual needs of the profit driven consumer society. So what can we learn from the past? There are at least two traditional building arts (the Chinese feng shui and the Indian vastu) that approach the design of a supportive living environment from a holistic point of view, adding a spiritual dimension to an otherwise very material-oriented design process. They both grew out of complex philosophical systems which need to be taken into account if we wish to extract the essence and not just copy- paste a form without the proper understanding of the content. One of the most basic differences between contemporary design practice and these two traditional building arts is in the conceptual understanding of the universe. Feng shui and vastu both claim that there is a life force that permeates everything. The Indians call it prana, the Chinese call it qi. Qi is supposed to be the life itself. Qi is the force that is manipulated and activated by Chinese acupuncture healing and it is the force used in Marshal Arts. But $Q i$ is no longer only a metaphysical concept but also an object of scientific research. Experiments by dr.Yan Xin (2015) [17] prove, that qi can be accumulated and directed through the body for healing purposes. Feng shui claims that through proper design of built environment the influences of this qi life force can be used, enhanced or manipulated to achieve a more supportive living environment. Apart from the qi life force, the concept of five phases $[18,19]$ and the concept of eight hexagrams [19] form the basic philosophical spine of feng shui methods. There are two main approaches in feng shui, the School of form and the School of Compass, which developed at the same time in two different parts of China from the same philosophical background. The School of form is more concerned with the intuitive reading of the landscape and it its forms, the school of Compass is more analytical and mathematical [20].

The School of Form analyses the flow of the Qi in the landscape, the so called Dragon veins, and it tries to place the building in the right position as to get the most of the surrounding environment, and to protect it from the unfavourable influences. The wind and the water, as already suggested by the name of the art (feng means wind and shui means water), are of utmost importance in feng shui. So basically feng shui tries to find the situations in the landscape, which give protection from the wind and openness to the favourable waters. In the school of form the shapes of the mountain ridges are of special interest. Mountains are equalled with Dragons, since the word dragon is the 
same as the one for the mountain. So to find the best place for the house, the master had to "ride the dragon" [21] or search the mountain slopes for the Qi or Dragon veins. Similar as the blood circulation works in the human body, the Earth, as a living creature, has a Qi vein system that enlivens her body. It is also important to which of the five phases, according to the system of the five phases, the mountain ridge or shape in the landscape can be attributed [22]. Another important issue is the structure of the water currents and roads in the vicinity of the building plot. Water is supposed to aqumulate the qi and the wind is the one that disperses it [23]. This offers another explanation why the houses beside lakes and see achieve better prises and why a public square with a water fountain is usually more attractive than the one without. The intensity of the Qi of the water currents around the building should be harmonious, not too wild and not too stagnant. Another important concept in the School of form is the concept of the five animals, with which the ancient Chinese defined the space arrangement in which we feel protected and in charge of the situation. The turtle is the one protecting our back, the tiger and the dragon guard our flanks and the bird Fenix in front of the structure is the one giving us the space to supervise the situation. This is the same pattern as was identified through environmental psychology with the concept of the refuge and prospect [4]. And the ancient Chinese communicated it through symbolic feng shui animals [24]. Apart from analysing the surrounding of the building plot the School of Form developed a wide set of recommendations for the design of the interior ranging from the bedrooms, kitchens, toilets up to the stores and offices [23, 25-27]. For example: our beds should be placed with the bed-head against a solid wall and the legs should not face the door, since this was associated with the position of the dead. There should be no heavy objects above the bed and the bed should not be positioned in the door - window or door - door straight line, since it is too dynamic and not supportive. Our office desks should be placed in the power position of the room: with our back protected and not against the door, with our desk in control of the whole space, overlooking the door and with a view out of the window, which corresponds with the prospect and refuge concept of the environmental psychology.

The other feng shui school, the School of Compass developed in the more flat northern part of China, where the knowledge of the reading of the land forms did not prove of much use. But instead the earth magnetism, analysed through the compass, was much more interesting. They observed that the magnetism is affecting the animals and concluded that it affects humans as well [28]. The school of Compass developed many methods of reading the compass orientation of the building and suggesting supportive and unsupportive areas for living. One of the most used is the East and West method [29], which divides all the buildings into two big groups: East group and
West group. Every building is supposed to have four supportive segments and four unsupportive ones, denoting eight qi patterns, originating from the eight trigrams. Furthermore a west or an east preference can be assigned to a person according to one's birth date. It may be of interest to note, that one of the supportive segments in East and west method is supposed to be linked with health issues and bears the symbolic name of Heavenly Doctor. A more elaborate School of Compass method deals with the concept of time, or with the probabilities for the things to happen in a specific space-time frame. The ancient Chinese have a long history of divination, and feng shui is actually just one of the divination technics they were using [22]. The Xuan Kong method [20,30 ], also referred to as Flying Star feng shui [31], uses the model of nine floating stars, to calculate the probabilities of favourable or unfavourable events in a specific part of the building. The stars or the numbers are used as symbols, but they are supposed to represent the influence of other stars and planetary bodies influencing the happenings on the earth. So it can happen, that part of a building or an office or a bedroom is supportive in a specific time frame and unsupportive in another. The unsupportive influences can be harmonised with the right use of the five phases (popularly called five elements): the fire, the earth, the metal, the water and the wood. With celestial influences involved, feng shui embraces a much wider dimension than just the immediate environment of the building and introduces a space-time concept that has no parallel in contemporary design practice.

\section{Results and Discussion - Vital house concept}

The findings of environmental psychology show, that although we can't say that the environment is the only factor shaping our behaviour in a particular build space, the elements of the environment are the ones co-creating our behavioural responses [32] and when taken into account properly can help us design a more supportive space better adjusted to our needs. And this information can be of great value to the designers interested into a supportive living environment. On the other hand, traditional art of feng shui proves to be a well-structured apparatus that demonstrates how a specific spiritual concept can be used in the design of the supportive environment. Although there are only few scientific evaluations concentrating on design process $[33,34]$ some research show, that following feng shui recommendations can actually help design a more efficient living environment [35, $36,37]$. Other comparative studies show, that some recommendations of feng shui and environmental psychology partly overlap [5, 38]. The aim is to com- 
bine these two concepts with contemporary architectural practice and its values of functionality, sustainability, technical perfection, low energy and sensory pleasingness. Psychological space intelligence is already partly incorporated in contemporary architecture but the practical use of the information already gathered could be more intense. But the spiritual ideas of oneness of everything, the existence of a life qi force and the earth as a living being [39] are currently not part of a contemporary designer's agenda. However, there is at least one project, the Vital house [40], that tries to bring this different approaches under one umbrella. It takes into account all the contemporary values of functionality, technical perfection and energy sustainability with good sun orientation and sensitivity to outside views. It stresses the importance of the use of traditional natural materials like wood, stone, brick and straw. It incorporates the knowledge of environmental psychology and its recommendations about colours, shapes, light, nature and arrangements of space according to different usages. And it also follows the traditional recommendations of feng shui and its school of compass and school of form recommendations, using the most supportive rooms of the house for the main entrance and the bedrooms and correcting the time-space influences by the correct use of the five phases. It goes even beyond feng shui by applying other spiritual approaches. The building plot is investigated by a professional dowser who identifies possible radiation of water currents, earth's nets (Curry and Hartmann nets), geological breaks and similar [41]. Geomancers are invited to harmonise the site and the indwelling spiritual beings of the site [42], following the understanding that the Earth is a vast leaving creature, a mother to all leaving beings [43]. Special care is taken as to the choice of the used materials and ecological materials are favoured whenever possible. The vitality of the used materials and technologies is monitored during the design process by dowsing method and Bovis scale. Special care is taken for the water, air and treatment of waste. Mechanical and vitalising water filters are used, mechanically treated air flow is reduced to the minimum and wastewater is treated through vegetable arrangements whenever possible. However, there is one feature that makes this house quite unique. It is its softly curved shape that is derived out of the qi life force concept. Qi is supposed to have a specific way of movement, mimicking the one of the wind and the water, travelling in soft curvy lines through the landscape, enlivening it along the way.

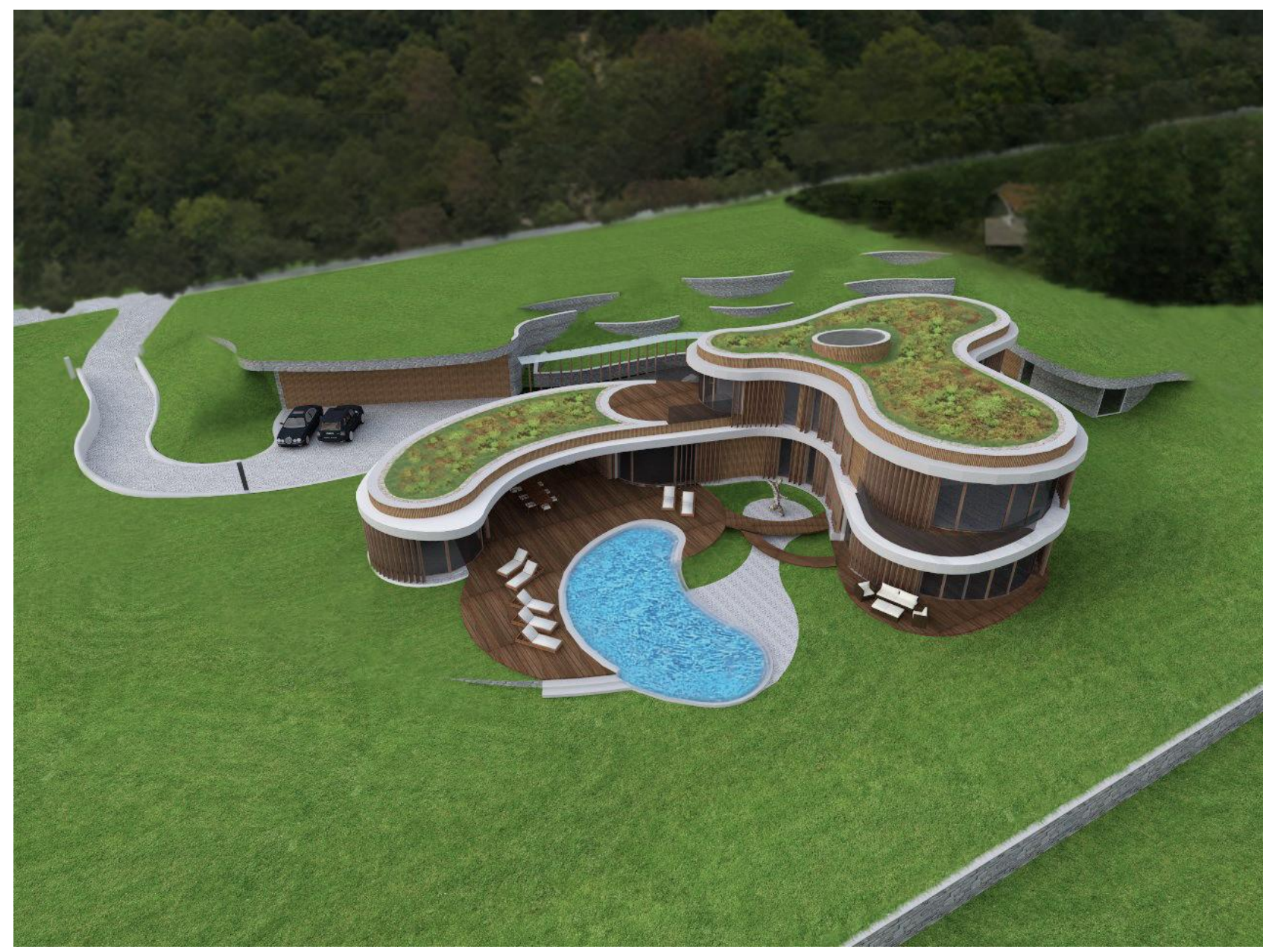

Figure 1: Vital house P, Preddvor, Arhitelje, 2014. Source: Arhitelje (2014) 
So, the architecture that would herald this life supporting way of movement should have no sharp or rectangular corners or long straight lines. In nature there are no long strait lines and orthogonal corners. If there are, they usually mark a powerful or dangerous space arrangement (like cliff or waterfall). The nature that supports life moves in soft curves, the hills of the landscape have curvy forms, the rivers flow (or used to flow) in soft meanders. Even the research of the environmental psychologists confirms that people prefer curvy forms to straight lines [4]. The curvy form is dynamic, mysterious (it does not show everything at once, but invites us to slowly discover along the way) and soft. It is the symbol of the feminine aspect which could form a desired counterpart to an otherwise predominantly technical and utilitarian contemporary built world.

Four projects bearing some or all of the elements above were designed since the establishment of the vital house concept in 2011: garden design Alpine Zen [44], interior design of flat Z [45], concept design for a Green growth centre Berkana [46] and a private villa Vital house $P$ [47]. The last one got the building permit in 2015. When finished, the house is expected to be a vibrant, healthy, well designed and supportive living environment tailored for the particular location as well as for its users.

\section{Acknowledgement}

The paper was presented at 3rd International scientific conference "SCIENCE AND CULTURE FOR A HEALTHY SOCIETY", organised by ALMA MATER EUROPAEA, $20^{\text {th }}-21^{\text {th }}$ March 2015, Maribor, Slovenia, and published in a peer reviewed Collection of scientific papers from the conference.

\section{References}

1. Churchill W. We shape our buildings. The Churchill centre. Available at:

http://www.winstonchurchill.org/learn/speeches/quotations/famous -quotations-and-stories (31.1.2015)

2. Polič M. Okoljska psihologija - univerzitetni učbenik. Ljubljana: Univerza v Ljubljani, odde ek za psihologijo, 1999: 4.

3. Bell A B, Green T C, Fisher J D, Baum A. Envi-ronmental psychology. Mahwah, New Jersey, London: Lawrence Erlbaum associates, 2001.

4. Augustin S. Place advantage. Hoboken, New Jer-sey: Wiley\&Sons, 2009.

5. Kryžanowski Š. Feng shui - primerjalna študija izbranih tradicionalnih priporočil in sodobnih dognanj. Magistrsko delo. Ljubljana: Univerza v Ljubljani, Fakulteta za arhitekturo, 2012: 214-227.

6. Mehrabian A, Russell J A. An approach to envi-ronmental psy- chology. Cambridge, MA: MIT Press, 1974.

7. Ulrich R S. Visual landscapes and psychological well-being. Landscape Research. 1979;4:17-23 http://dx.doi.org/10.1080/01426397908705892

8. Kaplan S. The restorative benefits of nature: to-ward an integrative framework. Journal of Envi-ronmental Psychology. 1995;15:169-182.

http://dx.doi.org/10.1016/0272-4944(95)90001-2

9. Ulrich RS. View through a window may influence recovery from surgery. Science. 1984;224: 420-421.

http://dx.doi.org/10.1126/science.6143402

10. Ulrich RS. Health Benefits of Gardens in Hospi-tals. In: Plants for people. Proceedings for International Exibition Floriade, 2002. Available at:

http://jarrettservices.com/resources/HealthBenefitsofGardensinHo spitals.pdf (24.12.2014)

11. Ulrich RS. Natural versus urban scenes: Some psychophysiological effects. Environment and Behavior. 1981;13:523-556. http://dx.doi.org/10.1177/0013916581135001

12. Heerwagen J, Orians G. The psychological as-pects of windows and window design. In: Pro-ceedings of 21st annual conference of the Envi-ronmental Design Research Association, 1990. Oklahoma City: EDRA, 1990:269-280.

13. Cooper-Marcus C, Barnes M. Gardens in healthcare Facilities: Uses, Therapeutic Benefits and design recommendations. Martinez CA: Cen-ter for Health Design, 1995.

14. Ulrich R S, Giplin L. Healing arts. In: Frampton S, Giplin L, Charmel P, eds. Putting Patients First. San Francisco: Jossey Bass, 2003:117-146.

15. Heschong L, Wright R L, Okura S. Daylighting Impacts on Human Performance in School: Jour-nal of the Illuminating Engineering Society, 2002: 101-114. Available at: http://scholar.google.si/scholar?hl=sl\&scioq=Daylighting+Impacts + on+Human+Performance+in+School\&q=Daylighting+Impacts+on+ Human+Performance+in+School\&btnG $=(24.12 .2014)$

16. Le Corbusier. Towards an Architecture. Mineola: Dover publications, 1985

17. Yan X. Dr. Yan Xin on Scientific Qigong Research. Available at: http://homepages.ihug.co.nz/ sai/DrYan_qi.htm (15.9.2015)

18. Ju Lan F. Istorija kineske filozofije. Beograd: No-lit, 1977:153157.

19. Milčinski M eds. Yijing - Knjiga premen. Ljubljana: Domus, 1992.

20. Wong E. Feng shui. Boston \& London: Shamba-la, 1996

21. Skinner $S$. The living earth manual of feng shui. Harmondsworth: Arkana - Penguin, 1982:2.

22. Kubny M. Feng shui, die Struktur der Welt. Dra-chen Verlag, 2008.

23. Wong E. A Master Course in Feng Shui. Boston \& London: Shambala, 2001.

24. Field S.L. An Overview of Ancient Fengshui. Feng shui gate. Available at: http://www.fengshuigate.com/overview.html (5.9.2006)

25. Lim J T Y. Feng shui und Gesundheit. Sulzberg: Joy Verlag, 1997:71-83

26. Lim JTY. Feng shui fur Buero und Business. Muenchen: Integral, 2000 .

27. Brown S. Feng šui v praksi. Ljubljana: Mladinska knjiga, 2000.

28. Needham. Science and civilisation in China, 1962; 4(1):262.

29. Sang L. The principles of feng shui. Monterey Park: The american feng shui institute, 2004. 
30. Moran E, Yu J, Biktashev V. The complete Idiot's guide to Feng Shui, third edition. New York: Alpha books, 2005.

31. Too L. The Complete Illustrated Guide to Feng Shui. Rockport MA: Element Books Ltd, 1996.

32. Mak M J, Ng S T. The art and science of Feng Shui - a study on architects' perception. Building and Environment.

2005;40(3):427-434.

http://dx.doi.org/10.1016/i.buildenv.2004.07.016

33. Mak M J, Ng S T. Feng shui: an alternative framework for complexity in design. Architectural Engineering and Design Management. 2008;4 (1): 58-72.

http://dx.doi.org/10.3763/aedm.2008.S307

34. Ke T. A preliminary study of Luan Tou feng shui landscapes and psychological reactions. Journal of Psychology in Chinese Societies. 2004;5:265.

35. Poulston J, Bennett R. Fact, fiction, and feng shui: an exploratory study. Facilities. 2012;30(1/2):23-39. http://dx.doi.org/10.1108/02632771211194257

36. Pheng L S, Xiaopeng D, Ting, Q L. Assimilating total building performance mandates with Chinese geomancy principles and scenarios. Facilities. 2012;30(13/14):558-589. http://dx.doi.org/10.1108/02632771211270568

37. Bonaiuto M, Bilotta E, Stolfa A. Feng shui and Environmental psychology: a critical comparison. Journal of Architectural and planning research. 2010;27(1):23-34.

38. Kryžanowski Š. Managing spirituality through de-sign process. In: proceedings for A.L.I.C.E. Inter-national design week, November 2014. Ljubljana: Faculty of design (in the process of publishing).

39. Arhitelje. Vital house conceptual project. Arhitelje, 2011. Available at: http://arhitelje.wix.com/vitalnahisa\#!home/con3 (25.12.2014)

40. Oblak SA. Moja šola radiestezije in bioenergije. Škofja Loka: Samozaložba, 1989.

41. Pogačnik M. Skrivno življenje zemlje. Mengeš: Bird publisher, 2010.

42. Lovelock J. Gaja se maščuje. Mengeš: Ciceron, 2007.

43. Arhitelje. Landscape project Alpine Zen. Arhitelje, 2012. Available at: http://arhitelje.wix.com/vitalnahisa\#!projects/c1gzy (25.12.2014)

44. Arhitelje. Interior design of flat Z. Arhitelje, 2014. Currently under construction.

45. Arhitelje. Green growth centre Berkana. Arhitelje, 2012. Available at: http://arhitelje.wix.com/vitalnahisa\#!projects/c1gzy (25.12.2014)

46. Arhitelje. Private villa Vital house P. Arhitelje, 2014. Available at: http://arhitelje.wix.com/vitalnahisa\#!projects/c1gzy (25.12.2014) 